\title{
Георги Гочев
}

\section{След „Медея“, или за общото между магията и превода}

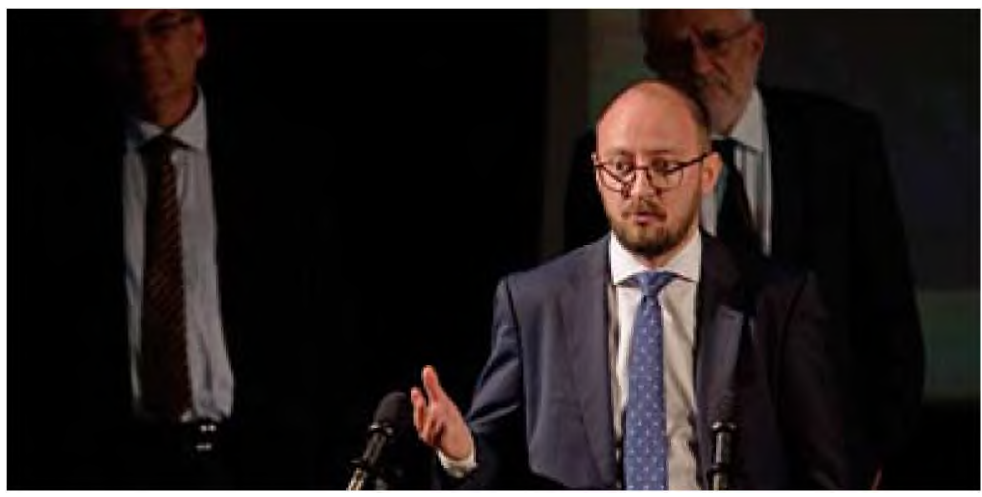

фотограф: Косьо Хаджигенчев

Медея е един от античните образи и сюжети, които се завръщат непрекъснато в различни контексти. Преди десетина години се появи нов превод на английски от влиятелния британски поет Робин Робъртсън, който формулира задачата си да бъде верен на гръцкия оригинал толкова, колкото и на днешния говорим английски. Кога и как усетихте, че пак идва времето на „Медея“ на български, че си струва да се направи нов превод? И каква беше за Вас основната „задача на преводача“" тук и сега?

Конкретният момент беше през лятото на 2017 г., когато Снежина Петрова ми се обади и ми предложи да преведа текста за представлението на Десислава Шпатова. Този превод се появи, така да се каже, по поръчка, обратно на обичайната практика, в която преводачът превежда и след това се надява, че някой режисьор ще постави текста му на сцена.

Това е дванадесетият превод на „Медея“ на български и ние се шегуваме, че цифрата не е случайна. 12 е магическо число, а самата Медея е магьосница. И действително, така стана, че през цялото време ние не изпълнявахме задачи, а участвахме в една магия: от самия превод, през работата ни с децата, та до представлението в Античния театьр - с онази невероятна лятна буря.

Преводът и магията си приличат. Едно трябва да се превърне в друго. Само че при превода друг става само текстьт, докато при магията други стават хората. Никой от нас вече не е същият след тези три години. 
Георги Гочев (р. 1981 г.) е класически филолог, университетски преподавател и преводач от старогръцки. Om 2009 г. преподава антична литература и класически езици в НБУ. Преводач е на "Държавата" и "Пир" от Платон, на "Поетиката" от Аристотел, на "Медея" от Еврипид (съвместно с поетесата Петя Хайнрих). Носител на националните награди за хуманитаристика "Христо Г. Данов" (2016) и "Проф. Богдан Богданов" (2019, заедно със Снежина Петрова).

Доколко работата по текста беше „интерактивна“ - свързана със сценичната версия на Снежина Петрова, с уъркшопите с деца, с решението да има детски хор?

От самото начало беше интерактивна във всички посоки: и от текста към обученията, и от обученията към сцената, и от сцената и обученията към текста. Не беше простата линейна енергия на практическите действия, а като в магия - енергията се въртеше. Първоначалната ни идея беше да преразкажем мита за Медея на децата, които трябваше да участват в представленията, но със Снежина решихме да не преразказваме, а да разиграем мита като социодрама. Така с Александра Гочева, която водеше социодраматичните обучения, направихме нещо като осъвременен превод на мита. Медея е изоставена в хотел с двете си деца, Язон тръгва да се жени за по-богата жена и децата трябва да довършат по свой начин този сценарий.

Така в представлението влязоха не само децата, но и част от техните игри. Играта, с която започва представлението - войната между двете царства - е взета почти дословно от социодраматичния сценарий. Така тази енергия, създадена от обученията - този запас от емоции, символи, идеи - не се разпиля, не беше оставен настрана, ами беше интегриран в спектакъла. Тук проличава едно чисто човешко качество на Деси Шпатова: нейната рядка способност да отстьпи. Докато масовият режисьор иска да е режисьор на всичко, то Деси допусна в представлението много неща, които самата тя не беше режисирала.

И най-сетне, когато се превежда антична драма, поетическите размери или просто се пропускат - в името на някакво съдържание, или се предават съвсем формално, така че стоят като украса. Ако в нашия превод ритьмът не е украса, ами органична част от текста, тоест нещо като негов пулс, това се дължи най-вече на работата ни с децата, чиито игри носят автентичен ритъм, на работата ни със студентите, които вложиха сърце и душа в тази постановка, на самите актьори, с които обсъждахме дори уместността на конкретни думи - няма да забравя един разговор с Койна Русева, която не приемаше наличието на думата „хич“ в монолога на вестителя - и не на последно място, на късмета да се сработим с композитор като Асен Аврамов - човек, който разнищва текста до фонеми.

За „Медея“ получихте наградата „Богдан Богданов“, честито! Случвало ли се е да обсъждате текста на Еврипид с професор Богданов?

Обсъждали сме го - да, при това неведнъж. Проф. Богданов има специфична теория за античната драма и тя е, че трагедиите, които ние познаваме, са нещо като 

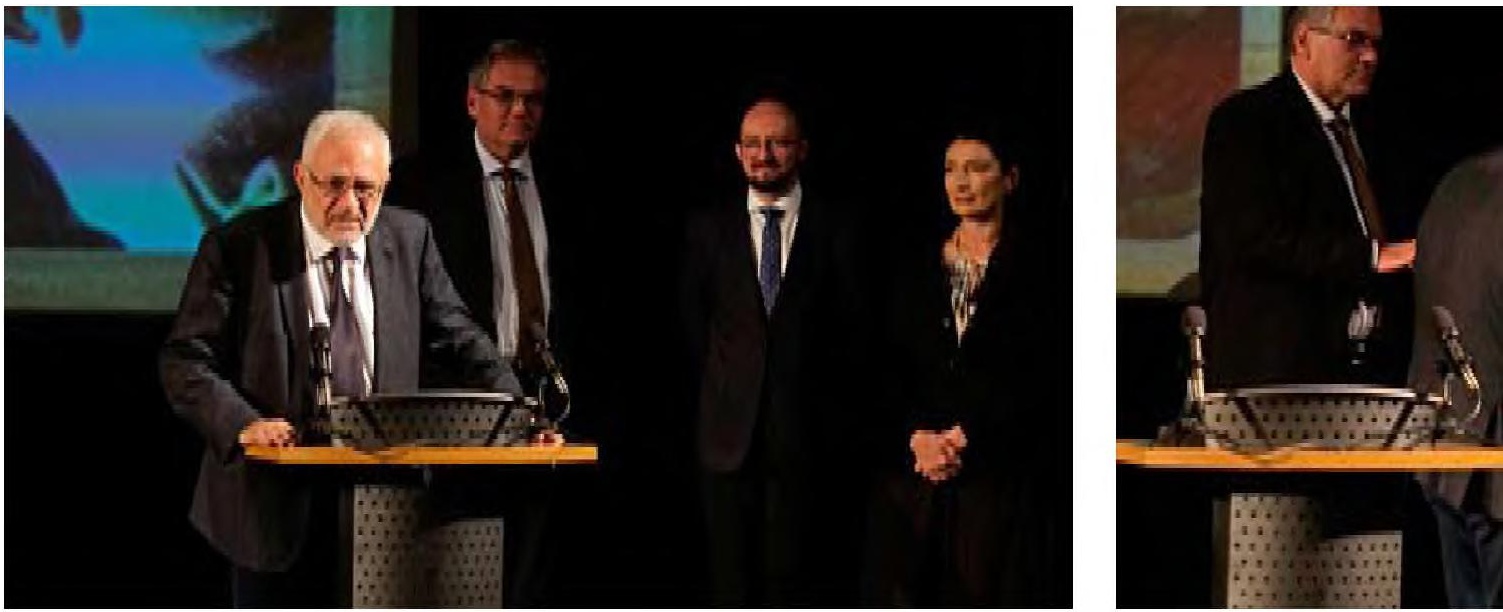

вторичен мит. Какво означава „вторичен мит“? Означава някакво митологическо съдържание, съществуващо под устна форма, което се преправя от драматурзите на Древна Атина, така че да обслужва определени цели на контекста. Това, което ние направихме, беше именно вторичен мит. Взехме едно митологическо съдържание от трагедията на Еврипид и го преведохме така, че да послужи на нашия контекст. Но вижте, проф. Богданов за мен не е само проф. Богданов от книгите и семинарите. Той е и гласът на моя вътрешен учител, на вътрешната ми самооценка. Едно този глас одобрява силно - тази човешка свързаност, която постигнахме в екипа на „Медея“, докато към друго е критичен. Това, към което е критичен, е самият текст, който в диалозите и монолозите е много по-добър, отколкото е в хоровите партии. Тази едва ли не барокова пищност, тази чиста декламация на хора продължава да ми се изплъзва. И преди не я разбирах, и сега не я разбирам повече.

Ето това вероятно би ми казал проф. Богданов: че парадоксално съм се справил подобре като човек, който участва в хор, отколкото като специалист по разчитане на хоровите песни.

\section{Създаде ли ви работата по този проект усещане за праговост, за „преди и след“} и какво идва след „Медея“ за Вас лично, за Вас като изследовател и преводач на старогръцка литература, за Вас като преподавател в НБУ?

От всичко казано по-горе, мисля, че отговорът е категорично - да.

Като класически филолог аз съм обучен да тълкувам рационално текста, съответно да преподавам някакви поуки от него, добити по рационален път. След „Медея“ започвам да си давам сметка, че текстовете имат и една емоционална логика, която често тече по съвсем различен начин. Тоест, който иска да познава добре текста, трябва да познава и собственото си преживяване с него.

Класическата филология може да ми каже, че митьт за Медея има тази и тази 

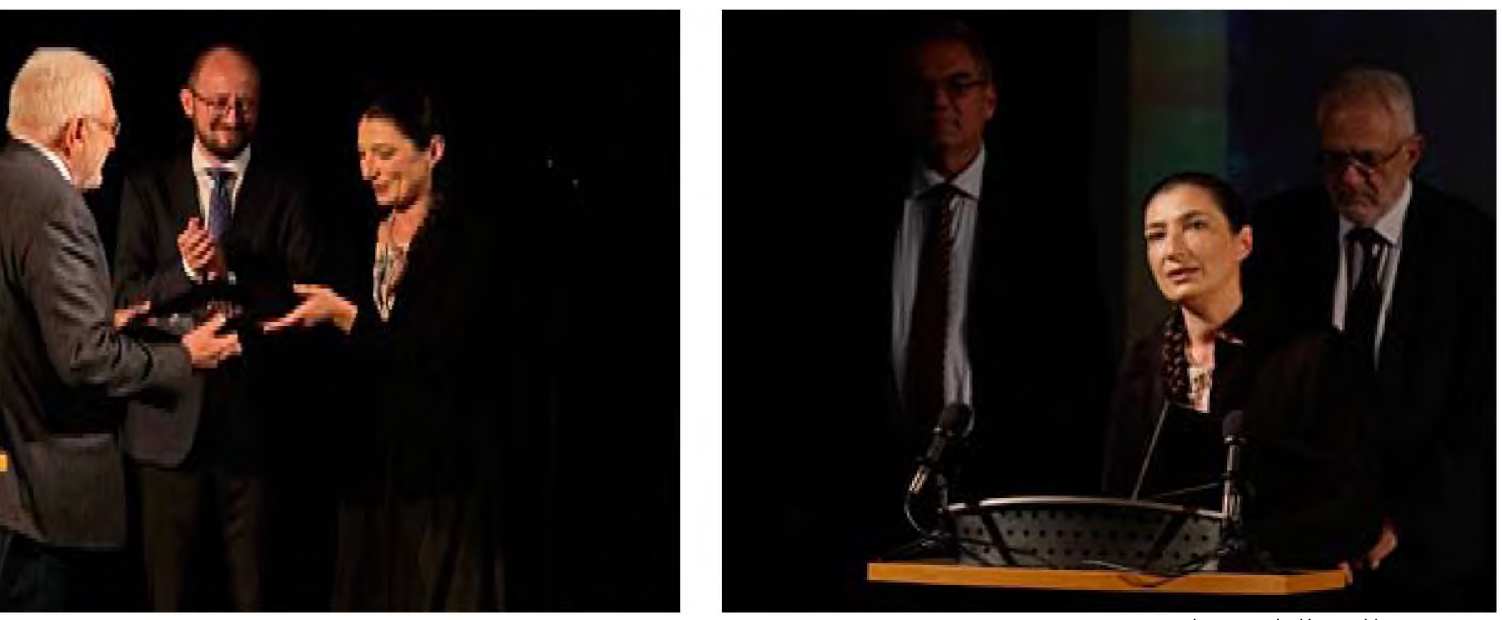

фотограф: Косьо Хаджигенчев

версия, че Еврипид може би е копирал един енигматичен драматург на име Неофрон, че няколко месеца след поставянето на „Медея“ избухва Пелопонеската война, че в диалозите има ямби и анапести и че ямбът е комбинация от кратка неударена и дълга ударена сричка, но класическата филология не може да ми каже защо „Медея“ продължава да ни вълнува и защо, щом чуем комбинацията от неударена и ударена сричка, тялото ни веднага се настройва за конфликт и сблъсък.

Тези неща не могат да се рационализират, те трябва да се преживеят.

Та може би това е новото, което ме интересува и като преподавател: как в нашите аудитории да се говори по-малко и да се преживява повече. Съвременната масова култура е открила отдавна как да използва нуждата от преживяване и го експлоатира по един повърхностен начин, докато академичното ни знание стои настрана като някакъв странен бастион на разума, който много често нито е академичен, нито е особено разумен.

Въпросите зададе Б. Курташева 